\title{
Pengaruh Dosis Pupuk Organik dan Komposisi Media Tanam terhadap Pertumbuhan dan Hasil Tanaman Sawi Jabung (Brassica juncea L.)
}

\author{
Saptorini ${ }^{1 \star}$ dan Edy Kustiani ${ }^{1}$ \\ ${ }^{1}$ Fakultas Pertanian, Universitas Kadiri, Kediri, Indonesia \\ *Korespondensi: saptorini46@unik-kediri.ac.id
}

Diterima: 3 Januari 2019/Direvisi: 30 Januari 2019/Disetujui: 1 Maret 2019

\begin{abstract}
ABSTRAK
Penelitian ini bertujuan untuk mengetahui dosis pupuk organik cair MOL per polybag dan komposisi media tanam yang berpengaruh baik terhadap pertumbuhan dan hasil tanaman sawi jabung (Brassica juncea). Penelitian ini merupakan percobaan faktorial yang menggunakan rancangan acak lengkap (RAL) dengan 3 kali ulangan dan 2 faktor: (1) dosis pupuk organik MOL (150; 200; 250 dan $300 \mathrm{cc} /$ polybag) dan (2) komposisi campuran media tanam tanah top soil : pasir : pupuk kandang $(1: 1: 1)$; tanah top soil : pasir : pupuk kandang $(2: 1: 1)$; tanah top soil : pasir : pupuk kandang $(1: 2: 1)$ dan tanah top soil : pasir : pupuk kandang (1:1:2)\}. Data dianalisis menggunakan analisis sidik ragam yang dilanjutkan dengan Uji Beda Nyata Terkecil (BNT) pada taraf $5 \%$ apabila perlakuan berbeda nyata. Dari hasil penelitian menunjukkan adanya interaksi komposisi media tanam dan dosis pupuk organik MOL terhadap pertumbuhan dan hasil tanaman sawi jabung (Brassica juncea) pada semua parameter pengamatan, yaitu: tinggi tanaman, jumlah daun, luas daun, jumlah akar, panjang akar, berat basah dan berat kering tanaman per tanaman. Pertumbuhan tanaman terbaik ditunjukkan oleh perlakuan campuran tanah top soil : pasir : pupuk kandang (2:1:1) dan pupuk organik (MOL 300 cc/polybag), yang menghasilkan: rata-rata tinggi tanaman, jumlah daun, luas daun, jumlah akar dan panjang akar terbesar. Perlakuan campuran tanah top soil : pasir : pupuk kandang (1:1:2) dan pupuk organik MOL (300 cc/polybag) menunjukkan hasil tanaman terbesar, yaitu rata-rata berat basah tanaman per tanaman sebesar 116,267 gr dan rata-rata berat kering tanaman per tanaman sebesar 12,290 gr.
\end{abstract}

Kata kunci: Komposisi; Pupuk organik; Sawi jabung

\begin{abstract}
This research aims to determine the local microorganism liquid organic fertilizer MOL dose per polybag and the planting medium composition which has a good effect on the mustard greens (Brassica juncea) growth and yield. This research is a factorial experiment using a completely randomized design (CRD) with 3 replications and 2 factors: (1) MOL organic fertilizer (150;200; 250 and $300 \mathrm{cc} /$ polybag) dose and (2) the mix composition of growing media top soil : sand : manure (1:1:1); top soil : sand : manure (2:1:1); top soil : sand: manure (1:2:1) and top soil: sand: manure (1:1:2)\}. The data were analyzed using variance analysis followed by the least significant difference test (LSD) at the $5 \%$ level if the treatments were significantly different. The results showed that there was an interaction between the planting medium composition and the MOL organic fertilizer dose on the mustard greens (Brassica juncea) growth and yield on all observations parameters, namely: plant height, leaves amount, leaf area, roots amount, root length, wet and dry weight per plant. The best plant growth was indicated by the top soil : sand: manure (2:1:1) treatment and organic fertilizers (MOL $300 \mathrm{cc} /$ polybag), which resulted in: average plant height, leaves amount, leaf area, roots amount, and the largest root length. The top soil : sand : manure (1:1:2) treatment and organic fertilizer MOL (300 cc/polybag) showed the largest crop yield that is the average wet weight per plant is $116.267 \mathrm{gr}$ and the average dry weight per plant is $12,290 \mathrm{gr}$.
\end{abstract}

Key words: Compotitions; Organic fertilizer; Green mustard 


\section{PENDAHULUAN}

Salah satu komoditas penting dalam mendukung ketahanan pangan nasional serta pemenuhan gizi masyarakat adalah hortikultura khususnya sayuran (Arinong, 2014). Tanaman hortikultura terutama tanaman sayuran daun memegang peranan penting, karena lebih banyak mengandung vitamin dibanding sayuran jenis lain (Subandi et al., 2015). Tanaman sawi adalah sekelompok tanaman hortikultura dari marga Brassica yang dimanfaatkan daunnya sebagai bahan pangan (sayuran), baik segar maupun olahan. Sawi adalah bahan pangan yang di konsumsil daunnya, sawi sering digunakan dalam kebutuhan sayuran sehari-hari. Sawi ini termasuk sayuran yang rendah kalori, dan mengandung serat yang baik untuk tubuh kita, selain itu juga terdapat kandungan Fosfor, Zat besi, Vitamin A, B1, B2, B3, dan C serta vitamin $K$ (Nurliana et al., 2017). Sawi (Brassica sp.) mencakup beberapa spesies, kadang-kadang mirip antara satu dengan yang lain. Genus Brassica umumnya hampir sama, mirip satu dengan yang lainnya. Macam-macam sawi yaitu sawi putih (sawi jabung), sawi hijau (sawi asin) dan sawi huma (pakchoi) (Perwtasari et al., 2012).

Di Indonesia penyebutan sawi biasanya mengacu pada sawi hijau (Brassica rapa) kelompok parachinensis, yang disebut juga sawi bakso, caisim, atau caisin. Selain itu, terdapat pula sawi putih (Brassica rapa) kelompok pekinensis, disebut juga petsai yang biasa dibuat sup atau diolah menjadi asinan. Jenis lain yang kadangkadang disebut sebagai sawi hijau adalah sawi sayur (untuk membedakannya dengan caisim). Kalao
(Brassica oleracea) kelompok alboglabra adalah sejenis sayuran daun lain yang agak berbeda, karena daunnya lebih tebal dan lebih cocok menjadi bahan campuran mie goreng. Sawi sendok (pakcoy atau bok choy) merupakan jenis sayuran daun kerabat sawi yang mulai dikenal pula dalam dunia boga Indonesia (Sarif et al., 2015).

Bila ditinjau dari aspek klimatologis, aspek ekonomis dan aspek sosialnya sangat mendukung untuk dikembangkan bisnis tanaman sayuran di Indonesia, di antara tanaman sayuran yang mudah dibudidayakan adalah tanaman sawi. Karena tanaman sawi sangat potensial untuk komersial dan prospeknya sangat baik (Sangaji, 2017). Sawi dalam perdagangan internasional dengan sebutan green mustard, chinnese mustard, indian mustard ataupun sarepta mustard.

Salah satu cara untuk memperbaiki pertumbuhan tanaman sawi adalah dengan penggunaan pupuk yang tepat. Pemupukan merupakan pemberian unsur hara yang diperlukan oleh tanaman untuk memenuhi kebutuhan nutrisinya (Sulastri et al., 2018). Pemberian pupuk yang tepat dan seimbang akan menurunkan biaya pemupukan (Alavan et al., 2015). Pupuk merupakan salah satu kebutuhan pokok yang harus dipenuhi untuk meningkatkan hasil pertanian. Pupuk dibedakan menjadi dua, yaitu pupuk organik dan pupuk anorganik. Pupuk organik merupakan pupuk yang baik untuk meningkatkan kesuburan tanah karena mengandung unsur hara makro dan unsur hara mikro dengan tetap menjaga struktur dan tekstur tanah yang baik. Unsur hara yang diserap tanaman akan dimanfaatkan dalam metabolisme, sehingga pertumbuhan 
tanaman menjadi lebih baik (Wicaksana \& Sulistyono, 2017).

Sedangkan pupuk anorganik merupakan pupuk kimia yang diproduksi pabrik, mengandung sebagian besar unsur hara makro tetapi sedikit kandungan unsur hara mikro, dan kelemahannnya strukstur dan tekstur tanah menjadi padat dan rusak. Banyak petani masih menggunakan pupuk anorganik karena mudah didapat, walaupun dengan harga mahal. Sebagian besar petani di negara berkembang seperti di Indonesia masih menggantungkan penggunaan bahan kimia dalam pengendalian penyakit tanaman serta pemupukan tanaman (Rinanto et al., 2015). Selanjutnya pupuk anorganik tersebut dapat berbahaya bagi lingkungan terutama dapat merusak lahan, yaitu strukstur lahan menjadi keras. Kerusakan tanah pertanian dapat diperbaiki salah satunya dengan cara pemberian bahan organik, yaitu mengurangi pupuk kimia dan menambahkan pupuk organik (Junaidi, 2017). Oleh karena itu dalam budidaya tanaman dianjurkan pupuk yang digunakan pupuk organik (Sutarya dan Grubben, 1995).

Di Indonesia ketergantungan pada pupuk anorganik menyebabkan terjadinya peningkatkan harga pupuk, akhirnya membuat petani tidak untung, walaupun produksinya meningkat. Dengan penggunaan pupuk kimia, dapat menimbulkan kerentanan terhadap hama dan penyakit. Penggunaan pupuk anorganik dalam budidaya tanaman dapat mengakibatkan produk pertanian dari Indonesia tidak memiliki nilai jual di pasar dunia, alasannya karena terkontaminasi pestisida. Di sisi lain, penggunaan pupuk anorganik akan meningkatkan penggunaan lahan secara intensif yang dapat mengakibatkan pengurasan hara dan bahan organik secara terus menerus. $\mathrm{Hal}$ ini di perburuk lagi dengan iklim tropis yang memiliki suhu dan curah hujan tinggi, sehingga intensitas tingkat pelapukan dan dekomposisi bahan organik, serta hara akan mudah hilang melalui pencucian (Musnamar, 2005).

Kegiatan pertanian menghasilkan pencemaran lingkungan, degradasi lahan dan pangan tidak sehat akibat pemakaian sarana produksi berbahan anorganik sintesis, hal ini akan menjadi pendorong gerakan pertanian organik, sebagai salah satu alternatif pertanian modern. Pertanian organik bertujuan selaras dengan ekosistem alami. Idealnya meliputi seluruh aspek usaha tani di mulai dari bagaimana mengendalikan hama penyakit, mempertahankan kesuburan tanah baik fisik, kimia maupun biologis serta aspek keterpaduannya dengan lingkungan dan kesehatan (Blake, 1994).

Untuk menjaga kesuburan tanah, "natural farming" ala $\mathrm{Mr}$ Cho mengajarkan agar petani memproduksi sendiri pupuknya. Tiap daerah dan tiap lahan memiliki mikroorganisme masingmasing yang berbeda-beda. Mikroorganisme ini membantu meningkatkan kandungan hara tanah melalui proses dekomposisi. Selain itu juga perlu ditambahkan mikroorganisme dari tempat lain (misal hutan bambu atau hutan tropis) untuk menambah "kekayaan" tanah (Danarti dan Najiyati, 1994).

Larutan pupuk organik cair mikroorganisme lokal (MOL) adalah larutan hasil fermentasi berbahan dasar dari berbagai sumber daya alam tersedia dari setempat (lokal) bbaik dari hewan maupun tumbuhan (Jeksen \& Mutiara, 2018). Larutan MOL merupakan pupuk organik cair 
mengandung unsur hara makro dan mikro juga mengandung bakteri berpotensi sebagai perombak bahan organik, perangsang pertumbuhan dan sebagai agen pengendali hama dan penyakit tanaman, sehingga pupuk organik cair MOL dapat digunakan baik sebagai dekomposer pupuk hayati maupun sebagai pestisida organik terutama sebagai fungisida (Firdaus et al., 2014).

Larutan pupuk organik cair MOL mengandung unsur bakteri yang sangat berpotensi untuk merombak bahan organik sampah menjadi pupuk organik (Julita et al., 2013). Banyak bahan baku di sekitar kita yang dapat menghasilkan bahan organik dan mikroorganisme yang dapat memperbaiki kesuburan tanah (Iradhatullah et al., 2016). Pupuk organik cair berbahan dasar biasanya dibuat sangat sederhana yaitu dengan memanfaatkan limbah dari rumah tangga atau tanaman di sekitar lingkungan. Hal ini dikarenakan MOL dapat tumbuh di setiap bahan organik yang mengandung nutrisi dengan kadar air cukup (Amalia dan Widiyaningrum, 2016), misalnya sisa-sisa tanaman seperti bonggol pisang, gedebog pisang, buah-buahan busuk, jerami padi, sisa sayuran, nasi basi dan lain-lain. Keunggulan penggunaan MOL yang paling utama adalah murah bahkan tanpa biaya. Dengan memanfaatkan bahan-bahan yang ada di sekitar (Kurniawan, 2018).

Bahan utama dalam larutan pupuk organik cair MOL terdiri dari 3 jenis komponen, antara lain: Karbohidrat seperti air cucian beras, nasi bekas, singkong, kentang dan gandum. Glukosa seperti cairan gula merah, cairan gula pasir, air kelapa atau nira. Sedangkan sumber bakteri seperti keong mas, buah-buahan misalnya tomat, pepaya dan kotoran hewan. Mikroba perombak bahan organik merupakan aktivator biologis yang tumbuh alami atau sengaja diberikan untuk mempercepat proses dekomposisi dan meningkatkan mutu pupuk organik (Manullang et al., 2018). Beberapa keuntungan dari MOL antara lain: mendukung pertanian ramah lingkungan; dapat mengatasi permasalahan pencemaran limbah pertanian dan limbah rumah tangga; pembuatan serta aplikasinya mudah dilakukan; mengandung unsur kompleks dan mikroba yang bermanfaat dalam produk pupuk dan dekomposer organik yang dihasilkan; memperkaya keanekaragaman biota tanah (Danuji, 2017).

Keberlanjutan atau kontinuitas untuk tetap meggunakan pupuk organik merupakan hal yang terpenting dalam pertanian organik. Dalam rangka meningkatkan hasil dianjurkan menggunakan pupuk organik cair yang dapat menggantikan posisi pupuk majemuk anorganik (Kustiani, 2018). Kelebihan pupuk organik cair di antaranya mudah terserap berada di dalam jaringan tanaman terutama jaringan daun dan memperbaiki kualitas sayuran karena tidak menggunakan bahan kimia (Wulandari, 2015).

Adapun tujuan dari penelitian ini untuk mengetahui berapa dosis pupuk organik cair MOL per polybag dan komposisi media tanam mana yang berpengaruh baik terhadap pertumbuhan dan hasil tanaman sawi jabung (Brassica juncea).

\section{BAHAN DAN METODE}

Penelitian dilaksanakan di green house Fakultas Pertanian Univeritas Kadiri, Kediri yang dimulai pada bulan Agustus sampai dengan bulan 
September 2015. Penelitian lapang ini merupakan percobaan faktorial yang menggunakan rancangan acak lengkap (RAL) dengan 3 (tiga) kali. Faktor pertama adalah dosis pupuk organik MOL, terdiri dari: $150\left(D_{1}\right) ; 200\left(D_{2}\right) ; 250$ $\left(D_{3}\right)$ dan $300\left(D_{4}\right)$ cc per polybag. Faktor kedua adalah komposisi media tanam, terdiri dari, campuran tanah top soil (1) : pasir (1) : pupuk kandang (1) $\left(\mathrm{M}_{1}\right)$; campuran tanah top soil (2) : pasir (1) : pupuk kandang (1) $\left(\mathrm{M}_{2}\right)$; campuran tanah top soil (1) : pasir (2) : pupuk kandang (1) $\left(\mathrm{M}_{3}\right)$ dan campuran tanah top soil (1) : pasir (1) : pupuk kandang (2) $\left(\mathrm{M}_{4}\right)$. Data dianalisis menggunakan analisis sidik ragam dan dilanjutkan dengan Uji Beda Nyata Terkecil (BNT) taraf 5\% apabila perlakuan berbeda nyata.

Benih yang digunakan dalam penelitian adalah benih sawi varietas Ferina. Pindah tanam (transplanting) dilakukan saat bibit berumur 15 HST (mempunyai 4-5 helai daun). Media tanam dipersiapkan sesuai komposisi masing-masing perlakuan. Pemberian pupuk organik MOL yang pertama dilakukan sebelum penanaman bibit sawi, yang kedua diberikan tujuh hari setelah tanam dan selanjutnya setiap 5 (lima) hari sekali (diulang sebanyak 3 kali) sesuai dengan dosis perlakuan. Tanaman sawi dipanen pada umur 3040 hari setelah tanam.

Variabel yang diamati dalam penelitian ini adalah tinggi tanaman, jumlah daun. Luas daun, jumlah akar, panjang akar, berat basah tanaman dan berat kering tanaman. Tinggi tanaman, jumlah daun dan luas daun sawi diukur mulai umur 7 HST dengan interval 7 hari sekali sampai umur 1 bulan.

\section{HASIL DAN PEMBAHASAN}

\section{Tinggi Tanaman}

Hasil analisis ragam menunjukkan terjadi interaksi antara dosis pupuk organik MOL dan komposisi media tanam terhadap tinggi tanaman sawi pada umur pengamatan 14, 21, dan 28 HST ditunjukkan pada Tabel 1. Komposisi media tanam menunjukkan pengaruh nyata terhadap tinggi tanaman sawi hanya pada umur 7 HST.

Perlakuan kombinasi $\mathrm{M}_{4} \mathrm{D}_{4}$ menunjukkan nilai rata-rata tinggi tanaman tertinggi dan tidak berbeda nyata dengan perlakuan kombinasi $M_{1} D_{4}$ dan $M_{3} D_{4}$, pada pengamatan umur 14, 21, dan 28 HST. Hal ini dikarenakan pada perlakuan komposisi media tanam yang dikombinasikan dengan penambahan pupuk organik $\mathrm{MOL}\left(\mathrm{M}_{4} \mathrm{D}_{4}, \mathrm{M}_{1} \mathrm{D}_{4}\right.$, dan $\mathrm{M}_{3} \mathrm{D}_{4}$ ) mempunyai sifat fisika, kimia dan biologi tanah yang baik, struktur tanah remah, serta kandungan unsur hara tinggi.

Pada struktur media tanam yang remah akar tanaman dapat tumbuh dan berkembang dengan baik, selanjutnya akar ini dapat menyerap air dan unsur hara dari media tanam dengan cepat. Pada media tanam ini $\left(M_{4} D_{4}, M_{1} D_{4}\right.$, dan $\mathrm{M}_{3} \mathrm{D}_{4}$ ) kandungan unsur haranya tinggi karena adanya dekomposisi MOL pada media campuran kompos semakin cepat.

Tersedianya unsur hara yang banyak pada media tanam ini dan adanya kemampuan akar menyerap yang cepat, maka unsur hara dan air yang dapat diserap semakin banyak, kemudian unsur hara dan air ini selanjutnya ditranslokasikan ke daun melalui xylem batang. Karena unsur hara dan air sebagai bahan dasar fotosintesis yang dapat ditranslokasikan 
ke daun semakin banyak, maka laju fotosintesis semakin meningkat.

Dengan meningkatnya laju fotosintesis maka hasil fotosintesis semakin banyak, di mana hasil fotosintesis ini digunakan untuk pertumbuhan dan perkembangan tanaman, yaitu untuk pertumbuhan akar, batang dan daun. Karena hasil fotosintesis banyak sehingga per- tumbuhan akar, batang dan daun semakin meningkat. Pertumbuhan yang cepat ini ditunjukkan dengan rata-rata tinggi tanaman yang tinggi. Ketersediaan air dan unsur hara yang cukup di dalam tanah dan akar tanaman berkembang dengan baik maka laju fotosintesis semakin meningkat dan laju pertumbuhan tanaman semakin meningkat pula (Cholisoh et al., 2018)

Tabel 1. Pengaruh komposisi media tanam dan dosis pupuk organik MOL terhadap tinggi tanaman pada umur 14, 21, dan 28 HST

\begin{tabular}{cccc}
\hline \multirow{2}{*}{ Perlakuan } & \multicolumn{3}{c}{ Rata-rata Tinggi Tanaman (cm) } \\
\cline { 2 - 4 } & $\mathbf{1 4} \mathbf{~ h s t}$ & $\mathbf{2 1} \mathbf{~ h s t}$ & $\mathbf{2 8} \mathbf{~ h s t}$ \\
\hline $\mathrm{D}_{1} \mathrm{M}_{1}$ & $6,333 \mathrm{a}$ & $19,067 \mathrm{~cd}$ & $34,700 \mathrm{ab}$ \\
$\mathrm{D}_{1} \mathrm{M}_{2}$ & $7,167 \mathrm{abc}$ & $19,600 \mathrm{de}$ & $35,400 \mathrm{ab}$ \\
$\mathrm{D}_{1} \mathrm{M}_{3}$ & $8,333 \mathrm{bc}$ & $12,500 \mathrm{a}$ & $39,167 \mathrm{~b}$ \\
$\mathrm{D}_{1} \mathrm{M}_{4}$ & $9,167 \mathrm{~d}$ & $22,933 \mathrm{e}$ & $45,300 \mathrm{c}$ \\
$\mathrm{D}_{2} \mathrm{M}_{1}$ & $6,833 \mathrm{ab}$ & $13,167 \mathrm{a}$ & $33,700 \mathrm{a}$ \\
$\mathrm{D}_{2} \mathrm{M}_{2}$ & $7,100 \mathrm{abc}$ & $13,733 \mathrm{ab}$ & $33,233 \mathrm{a}$ \\
$\mathrm{D}_{2} \mathrm{M}_{3}$ & $7,000 \mathrm{abc}$ & $17,167 \mathrm{bc}$ & $37,033 \mathrm{ab}$ \\
$\mathrm{D}_{2} \mathrm{M}_{4}$ & $7,000 \mathrm{abc}$ & $12,233 \mathrm{a}$ & $37,233 \mathrm{ab}$ \\
$\mathrm{D}_{3} \mathrm{M}_{1}$ & $6,433 \mathrm{ab}$ & $15,767 \mathrm{abc}$ & $35,167 \mathrm{ab}$ \\
$\mathrm{D}_{3} \mathrm{M}_{2}$ & $7,500 \mathrm{abc}$ & $17,767 \mathrm{~cd}$ & $36,500 \mathrm{ab}$ \\
$\mathrm{D}_{3} \mathrm{M}_{3}$ & $7,167 \mathrm{abc}$ & $18,900 \mathrm{~cd}$ & $38,867 \mathrm{~b}$ \\
$\mathrm{D}_{3} \mathrm{M}_{4}$ & $9,467 \mathrm{~d}$ & $22,867 \mathrm{e}$ & $45,433 \mathrm{c}$ \\
$\mathrm{D}_{4} \mathrm{M}_{1}$ & $7,186 \mathrm{abc}$ & $13,667 \mathrm{ab}$ & $37,000 \mathrm{ab}$ \\
$\mathrm{D}_{4} \mathrm{M}_{2}$ & $6,800 \mathrm{ab}$ & $19,267 \mathrm{~cd}$ & $35,067 \mathrm{ab}$ \\
$\mathrm{D}_{4} \mathrm{M}_{3}$ & $8,833 \mathrm{~cd}$ & $15,767 \mathrm{abc}$ & $35,800 \mathrm{ab}$ \\
$\mathrm{D}_{4} \mathrm{M}_{4}$ & $9,500 \mathrm{~d}$ & $23,033 \mathrm{e}$ & $49,300 \mathrm{c}$ \\
\hline $\mathrm{BNT}_{1} \%$ & 1,981 & 3,763 & 5,138
\end{tabular}

Keterangan: Angka-angka yang diikuti huruf sama pada kolom yang sama tidak berbeda nyata $\mathrm{p}=0.05$ (Uji Beda Nyata Terkecil)

Pada pengamatan umur 7 HST hanya komposisi media tanam yang berpengaruh terhadap rata-rata tinggi tanaman sawi (Tabel 2.). Perlakuan $\mathrm{M}_{4}$ menunjukkan rata-rata tinggi tanaman tertinggi $(10,575 \mathrm{~cm})$ akan tetapi tidak berbeda nyata dengan perlakuan $M_{3}$ dan $M_{1}$. Hal ini dikarenakan komposisi media tanam $\mathrm{M}_{4}$ : tanah top soil: pasir: pupuk kandang (1:1:2), begitu juga dengan komposisi media tanam $\mathrm{M}_{3}$ : tanah top soil: pasir: pupuk kandang
(1:2:1) dan $M_{1:}$ tanah top soil: pasir: pupuk kandang (1:1:1) merupakan media tanam dengan struktur sangat remah. Struktur tanah seperti ini merupakan media yang dikehendaki oleh tanaman khususnya tanaman sayuran, karena di dalamnya terdapat ruang pori-pori yang dapat diisi oleh udara dan air tanah yang sangat penting untuk pertumbuhan dan perkembangan akar (Gustia, 2013). 
Tabel 2. Pengaruh dosis pupuk organik MOL dan komposisi media tanam I tanaman pada umur 7 HST

\begin{tabular}{cc}
\hline Perlakuan & $\begin{array}{c}\text { Rata-rata Tinggi Tanaman Umur } 7 \text { hst } \\
(\mathbf{c m})\end{array}$ \\
\hline $\mathrm{M}_{1}$ & $9,950 \mathrm{ab}$ \\
$\mathrm{M}_{2}$ & $9,375 \mathrm{a}$ \\
$\mathrm{M}_{3}$ & $9,850 \mathrm{ab}$ \\
$\mathrm{M}_{4}$ & $10,575 \mathrm{~b}$ \\
\hline BNT: $5 \%$ & 0,774 \\
\hline $\mathrm{D}_{1}$ & 8,85 \\
$\mathrm{D}_{2}$ & 10,35 \\
$\mathrm{D}_{3}$ & 10,1 \\
$\mathrm{D}_{4}$ & 10,45 \\
\hline BNT: $5 \%$ & $\mathrm{NS}$
\end{tabular}

Keterangan: Angka-angka yang diikuti huruf yang sama pada kolom yang sama tidak berbeda nyata $\mathrm{p}=0.05$ (Uji Beda Nyata Terkecil)

Hasil fotosintesis selanjutnya dikirim kembali ke seluruh bagian tubuh tanaman untuk pertumbuhan dan perkembangan sel-sel. Hal ini terlihat dari adanya peningkatan pertumbuhan vegetatif tanaman yaitu bertambahnya tinggi tanaman.

Perlakuan dosis pupuk organik MOL belum memberikan pengaruh yang nyata pada umur 7 HST. Hal ini dikarenakan mikroorganisme dalam MOL yang diberikan belum maksimal aktivitasnya. Dan mikroorganisme ini akan meningkat aktivitasnya seiring dengan semakin lamanya waktu penggunaan, jadi semakin lama waktu aplikasi pupuk organik MOL maka aktivitasnya semakin meningkat (Erawan et al., 2013).
Jumlah Daun

Hasil analisis sidik ragam menunjukkan tidak terjadi interaksi antara dosis pupuk organik MOL dan komposisi media tanam terhadap jumlah daun tanaman sawi pada semua umur pengamatan (Tabel 3.).

Perlakuan dosis pupuk organik MOL dan komposisi media tanam tidak menunjukkan pengaruh yang nyata terhadap jumlah daun per tanaman. Hal ini dikarenakan jumlah daun per tanaman sangat dipengaruhi oleh faktor genetik. Jadi faktor luar baik seperti dosis pupuk organik MOL maupun komposisi media tanam tidak berpengaruh terhadap rata-rata jumlah daun per tanaman.

Tabel 3. Pengaruh dosis pupuk organik MOL dan komposisi media tanam terhadap jumlah daun pada umur 7, 14, 21, dan 28 HST

\begin{tabular}{ccccc}
\hline Perlakuan & \multicolumn{4}{c}{ Rata-rata Jumlah Daun } \\
\cline { 2 - 5 } & $\mathbf{7 ~ H S T}$ & $\mathbf{1 4}$ HST & 21 HST & 28 HST \\
\hline $\mathrm{M}_{1}$ & 6,50 & 10,75 & 19,50 & 25,25 \\
$\mathrm{M}_{2}$ & 5,25 & 10,25 & 19,25 & 25,25 \\
$\mathrm{M}_{3}$ & 5,25 & 10,00 & 19,75 & 30,50 \\
$\mathrm{M}_{4}$ & 5 & 9 & 19,25 & 31,75 \\
\hline BNT: $5 \%$ & $\mathrm{NS}$ & $\mathrm{NS}$ & $\mathrm{NS}$ & $\mathrm{NS}$ \\
\hline
\end{tabular}




\begin{tabular}{lcccc}
\hline $\mathrm{D}_{1}$ & 5,50 & 10,50 & 19,00 & 29,75 \\
$\mathrm{D}_{2}$ & 5,25 & 9,75 & 18,25 & 28,25 \\
$\mathrm{D}_{3}$ & 5,50 & 9,75 & 20,50 & 28,25 \\
$\mathrm{D}_{4}$ & 5,75 & 10,00 & 20,00 & 26,50 \\
\hline
\end{tabular}

BNT: $5 \%$

NS

NS

NS
NS

Keterangan: Angka-angka yang diikuti huruf yang sama pada kolom yang sama tidak berbeda nyata $\mathrm{p}=0.05$ (Uji Beda Nyata Terkecil)

\section{Luas Daun}

Hasil analisis sidik ragam menunjukkan terjadi interaksi antara perlakuan dosis pupuk organik MOL dan komposisi media tanam terhadap rata- rata luas daun per tanaman pada umur 14, 21, dan 28 HST (Tabel 4.). Sedangkan untuk pengamatan umur 7 HST tidak terjadi interaksi antara perlakuan dosis pupuk organik MOL dan komposisi media tanam.

Tabel 4. Pengaruh dosis pupuk organik MOL dan komposisi media tanam pada umur 14, 21 dan 28 HST

\begin{tabular}{|c|c|c|c|}
\hline \multirow[b]{2}{*}{ Perlakuan } & \multicolumn{3}{|c|}{ Rata-rata Luas Daun $\left(\mathrm{cm}^{2}\right)$} \\
\hline & $14 \mathrm{HST}$ & 21 HST & 28 HST \\
\hline$M_{1} D_{1}$ & $15,748 a b$ & $29,316 \mathrm{a}$ & 170,877 cde \\
\hline$M_{1} D_{2}$ & $24,088 \mathrm{c}$ & $49,527 d$ & $121,493 \mathrm{a}$ \\
\hline$M_{1} D_{3}$ & $10,721 a$ & $33,326 a b$ & $142,871 \mathrm{bc}$ \\
\hline$M_{1} D_{4}$ & $38,450 \mathrm{~d}$ & $63,644 \mathrm{e}$ & $192,576 \mathrm{fg}$ \\
\hline $\mathrm{M} \mathrm{D}_{1}$ & $14,208 a b$ & $43,870 \mathrm{~cd}$ & 183,090 ef \\
\hline$M_{2} D_{2}$ & 17,952 b & $44,007 \mathrm{~cd}$ & $157,293 \mathrm{~cd}$ \\
\hline$M_{2} D_{3}$ & $13,362 a b$ & $44,880 \mathrm{~cd}$ & $157,726 \mathrm{~cd}$ \\
\hline$M_{2} D_{4}$ & $23,014 \mathrm{c}$ & $30,260 a b$ & 168,119 cde \\
\hline$M_{3} D_{1}$ & $16,433 b$ & $24,570 \mathrm{a}$ & $152,909 \mathrm{c}$ \\
\hline$M_{3} D_{2}$ & $18,355 b$ & $40,217 \mathrm{c}$ & $175,066 \mathrm{de}$ \\
\hline$M_{3} D_{3}$ & $16,558 \mathrm{~b}$ & $27,391 \mathrm{a}$ & $199,256 \mathrm{fg}$ \\
\hline$M_{3} D_{4}$ & $33,399 d$ & $60,990 \mathrm{e}$ & $206,119 \mathrm{~g}$ \\
\hline$M_{4} D_{1}$ & $11,583 a b$ & $41,480 \mathrm{~cd}$ & $131,980 \mathrm{ab}$ \\
\hline$M_{4} D_{2}$ & $11,617 a b$ & 58,559 e & $135,288 a b$ \\
\hline$M_{4} D_{3}$ & $28,073 \mathrm{c}$ & $38,509 \mathrm{bc}$ & $176,687 \mathrm{de}$ \\
\hline $\mathrm{M}_{4} \mathrm{D}_{4}$ & $49,742 \mathrm{e}$ & $63,601 \mathrm{e}$ & $220,535 \mathrm{~g}$ \\
\hline BNT: $5 \%$ & 5,146 & 8,758 & 20,649 \\
\hline
\end{tabular}

Keterangan: Angka-angka yang diikuti huruf yang sama pada kolom yang sama tidak berbeda nyata $p=0.05$ (Uji Beda Nyata Terkecil)

Rata-rata luas daun tertinggi dicapai pada perlakuan $M_{4} D_{4}$ dan tidak berbeda nyata dengan $M_{1} D_{4}$ dan $M_{3} D_{4}$. Dosis pupuk organik MOL pada perlakuan $\mathrm{D}_{4}$ (300 cc per polybag) mampu mendekomposisi unsur dalam media tanam secara maksimal sehingga unsur hara tersedia bagi tanaman semakin banyak dan dapat diserap oleh akar tanaman.

Selanjutnya unsur hara ini diserap akar tanaman kemudian ditrans- 
lokasikan ke daun melalui xylem batang sebagai bahan dasar proses fotosintesis. Karena pupuk organik MOL yang diberikan pada tanah cukup tinggi aktivitasnya maka dapat menyediakan kebutuhan akan unsur hara $\mathrm{N}$ dalam jumlah cukup dan berimbang dengan kebutuhan unsur hara lainnya.

Ketersediaan beberapa unsur hara dalam jumlah cukup dan berimbang sangat diperlukan dalam berbagai proses metabolisme tanaman, termasuk dalam hal serapan terhadap sejumlah unsur hara lain dan sintesis senyawasenyawa organik yang sangat diperlukan dalam berbagai aktivitas pertumbuhan dan perkembangan tanaman.

Banyaknya karbohidrat yang terbentuk dalam proses fotosintesis sangat dipengaruhi oleh kemampuan daun di dalam menyerap energi radiasi matahari, tentunya berkaitan erat dengan jumlah dan luas daun tanaman bersangkutan. Sejumlah besar karbohidrat dihasilkan dalam proses fotosintesis tersebut dan digunakan tanaman untuk pertumbuhan dan perkembangan serta pembentukan hasil tanaman (Setyati, 1985 dan Hariyanto, 1995).

Tabel 5. Pengaruh dosis pupuk organik MOL dan komposisi media tanaman terhadap luas daun pada umur 7 HST

\begin{tabular}{cc}
\hline Perlakuan & Rata-rata luas daun $\left.\mathbf{( c m}^{2}\right)$ \\
\hline $\mathrm{M}^{1}$ & 10,89 \\
$\mathrm{M}^{2}$ & 10,71 \\
$\mathrm{M}^{3}$ & 10,72 \\
$\mathrm{M}^{4}$ & 10,77 \\
\hline $\mathrm{BNT}: 5 \%$ & $\mathrm{NS}$ \\
\hline $\mathrm{D}^{1}$ & 11.00 \\
$\mathrm{D}^{2}$ & 11.05 \\
$\mathrm{D}^{3}$ & 10.70 \\
$\mathrm{D}^{4}$ & 10.34 \\
\hline BNT: $5 \%$ & $\mathrm{NS}$
\end{tabular}

Keterangan: Angka-angka yang diikuti huruf yang sama pada kolom yang sama tidak berbeda nyata $p=0.05$ (Uji Beda Nyata Terkecil)

Perlakuan dosis pupuk organik MOL dan komposisi media tanam tidak berpengaruh nyata terhadap rata-rata luas daun pada umur 7 HST (Tabel 5.). Hal ini kemungkinan karena yang diberikan belum mampu mendekomposisi hara di dalam media tanam secara maksimal sehingga metabolisme tanaman hanya mengandalkan cadangan makanan yang tersimpan di dalam biji tanaman.

\section{Jumlah Akar}

Hasil analisis sidik ragam menunjukkan terjadi interaksi antara dosis pupuk organik MOL dan komposisi media tanam terhadap rata-rata jumlah akar per tanaman pada saat panen (Tabel 6).

Perlakuan $\mathrm{M}_{4} \mathrm{D}_{4}$ menunjukkan rata-rata jumlah akar terbanyak $(23,667)$ dan tidak berbeda nyata dengan perlakuan $\mathrm{M}_{1} \mathrm{D}_{4}(22,333), \mathrm{M}_{3} \mathrm{D}_{4}(22,967)$ akan tetapi berbeda nyata dengan perlakuan yang lain Hal ini disebabkan semakin banyak kompos dalam 
Tabel 6. Pengaruh dosis pupuk organik MOL dan komposisi media tanam terhadap rata-rata jumlah akar pada saat panen

\begin{tabular}{c|c}
\hline Perlakuan & Rata-rata Jumlah Akar Saat Panen \\
\hline$M_{1} D_{1}$ & $12,333 \mathrm{a}$ \\
$M_{1} D_{2}$ & $17,000 \mathrm{c}$ \\
$M_{1} D_{3}$ & $14,333 \mathrm{ab}$ \\
$M_{1} D_{4}$ & $22,333 \mathrm{f}$ \\
$M_{2} D_{1}$ & $15,333 \mathrm{bc}$ \\
$M_{2} D_{2}$ & $17,667 \mathrm{~cd}$ \\
$M_{2} D_{3}$ & $15,333 \mathrm{bc}$ \\
$M_{2} D_{4}$ & $19,333 \mathrm{~d}$ \\
$M_{3} D_{1}$ & $20,056 \mathrm{e}$ \\
$M_{3} D_{2}$ & $20,000 \mathrm{e}$ \\
$M_{3} D_{3}$ & $13,000 \mathrm{a}$ \\
$M_{3} D_{4}$ & $22,967 \mathrm{f}$ \\
$M_{4} D_{1}$ & $15,333 \mathrm{bc}$ \\
$M_{4} D_{2}$ & $15,333 \mathrm{bc}$ \\
$M_{4} D_{3}$ & $17,000 \mathrm{c}$ \\
$M_{4} D_{4}$ & $23,667 \mathrm{f}$ \\
\hline NT: $_{5} \%$ & 2,171 \\
\hline
\end{tabular}

Keterangan: Angka-angka yang diikuti huruf yang sama pada kolom yang sama tidak berbeda nyata $p=0.05$ (Uji Beda Nyata Terkecil)

campuran media tanam di tambah dengan dosis pupuk organik MOL 300 cc per polybag dapat.meningkatkan tersedianya hara lebih banyak, selanjutnya hara ini diserap oleh akar tanaman untuk dikirim ke daun sebagai bahan dasar proses fotosintesis.

Karena bahan dasar proses fotosintesis tersedia banyak maka laju proses fotosintesis semakin meningkat, di mana hasil dari proses fotosintesis ini digunakan untuk pertumbuhan dan perkembangan tanaman di antaranya untuk pertumbuhan akar, sehingga jumlah akar tanaman semakin banyak.

\section{Panjang Akar}

Hasil analisis sidik ragam menunjukkan terjadi interaksi antara perlakuan dosis pupuk organik MOL dan komposisi media tanam terhadap ratarata panjang akar pada saat panen. Kombinasi dosis pupuk organik MOL dan komposisi media tanam memberikan pengaruh nyata terhadap rata-rata panjang akar tanaman sawi (Tabel 7). Perlakuan $\mathrm{M}_{1} \mathrm{D}_{4}$ menghasilkan rata-rata panjang akar terpanjang $(17,500 \mathrm{~cm})$ sedangkan rata-rata panjang akar paling pendek $(9,8 \mathrm{~cm})$ dihasilkan perlakuan $\mathrm{M}_{2} \mathrm{D}_{2}$. Dosis pupuk organik MOL yang tinggi (300 cc per polybag) menyebabkan mikroorganisme mampu menguraikan bahan organik yang ada dalam media lebih efektif dan kemampuan untuk menahan air juga semakin meningkat sehingga struktur media menjadi remah. Struktur media tanam yang remah sangat baik untuk pertumbuhan akar menjadikan akar tumbuh lebih panjang.

\section{Berat Basah Tanaman}

Hasil analisis sidik ragam menunjukkan terjadi interaksi antara perlakuan dosis pupuk organik MOL 
Tabel 7. Pengaruh dosis pupuk organik MOL dan komposisi media tanam terhadap panjang akar pada saat panen

\begin{tabular}{cc}
\hline Perlakuan & Rata-rata Panjang Akar (cm) \\
\hline$M_{1} D_{1}$ & $12,333 \mathrm{bc}$ \\
$M_{1} D_{2}$ & $12,667 \mathrm{bc}$ \\
$M_{1} D_{3}$ & $11,000 \mathrm{ab}$ \\
$M_{1} D_{4}$ & $17,500 \mathrm{f}$ \\
$M_{2} D_{1}$ & $14,867 \mathrm{de}$ \\
$M_{2} D_{2}$ & $9,800 \mathrm{a}$ \\
$M_{2} D_{3}$ & $13,500 \mathrm{~cd}$ \\
$M_{2} D_{4}$ & $15,000 \mathrm{de}$ \\
$M_{3} D_{1}$ & $16,667 \mathrm{ef}$ \\
$M_{3} D_{2}$ & $15,167 \mathrm{de}$ \\
$M_{3} D_{3}$ & $16,333 \mathrm{ef}$ \\
$M_{3} D_{4}$ & $14,900 \mathrm{de}$ \\
$M_{4} D_{1}$ & $15,833 \mathrm{ef}$ \\
$M_{4} D_{2}$ & $17,333 \mathrm{f}$ \\
$M_{4} D_{3}$ & $12,233 \mathrm{bc}$ \\
$M_{4} D_{4}$ & $14,067 \mathrm{~d}$ \\
\hline$B_{1} 5 \%$ & 1,9
\end{tabular}

Keterangan: Angka-angka yang diikuti huruf yang sama pada kolom yang sama tidak berbeda nyata $p=0,05$ (Uji Beda Nyata Terkecil)

dan komposisi media tanam terhadap rata-rata berat basah tanaman pada saat panen. Kombinasi dosis pupuk organik MOL dan komposisi media tanam berpengaruh nyata terhadap berat basah tanaman (Tabel 8).

Rata-rata berat basah tanaman terberat ditunjukkan oleh perlakuan $\mathrm{M}_{3} \mathrm{D}$. $4(118,100 \mathrm{gr})$ dan berbeda nyata dengan perlakuan lain. $\mathrm{Hal}$ ini disebabkan karena pertumbuhan tanaman pada perlakuan $\mathrm{M}_{3} \mathrm{D}_{4}$ terbaik ditunjukkan oleh rata-rata tinggi tanaman tertinggi, jumlah daun terbanyak dan luas daun terluas serta jumlah akar paling banyak dan terpanjang. Dari semua variabel pengamatan tinggi tanaman, jumlah dan luas daun serta jumlah akar dan panjang akar menunjukkan hasil paling besar maka variabel berat basah tanaman juga paling besar.

\section{Berat Kering Tanaman}

Hasil analisis sidik ragam menunjukkan terjadi interaksi antara perlakuan dosis pupuk organik MOL dan komposisi media tanam terhadap ratarata berat kering tanaman pada saat panen. Kombinasi dosis pupuk organik MOL dan komposisi media tanam berpengaruh nyata terhadap berat kering tanaman sawi (Tabel 9). Ratarata berat kering tanaman terberat ditunjukkan oleh perlakuan $\mathrm{M}_{4} \mathrm{D}_{4}(12,290$ gr) dan tidak berbeda nyata dengan $\mathrm{M}$ ${ }_{3} \mathrm{D}_{4}(11,987 \mathrm{gr})$ dan $\mathrm{M}_{1} \mathrm{D}_{4}(10,20 \mathrm{gr})$, tetapi berbeda nyata dengan perlakuan lain. Hal ini disebabkan pada kombinasi perlakuan ini tanaman mempunyai pertumbuhan baik, ditunjukkan dari ratarata berat kering tanaman paling berat. 
Tabel 8. Pengaruh dosis pupuk organik MOL dan komposisi media tanam terhadap berat basah tanaman sawi ( $\mathrm{gr}$ )

\begin{tabular}{cc}
\hline Perlakuan & Rata-rata Berat Basah Tanaman (gr) \\
\hline$M_{1} D_{1}$ & $69,700 \mathrm{bcd}$ \\
$M_{1} D_{2}$ & $59,467 \mathrm{ab}$ \\
$M_{1} D_{3}$ & $81,867 \mathrm{def}$ \\
$M_{1} D_{4}$ & $112,833 \mathrm{~h}$ \\
$M_{2} D_{1}$ & $85,367 \mathrm{ef}$ \\
$M_{2} D_{2}$ & $51,667 \mathrm{a}$ \\
$M_{2} D_{3}$ & $64,400 \mathrm{abc}$ \\
$M_{2} D_{4}$ & $75,367 \mathrm{cde}$ \\
$M_{3} D_{1}$ & $59,100 \mathrm{ab}$ \\
$M_{3} D_{2}$ & $51,333 \mathrm{a}$ \\
$M_{3} D_{3}$ & $93,067 \mathrm{fg}$ \\
$M_{3} D_{4}$ & $118,100 \mathrm{~h}$ \\
$M_{4} D_{1}$ & $69,233 \mathrm{bcd}$ \\
$M_{4} D_{2}$ & $93,433 \mathrm{fg}$ \\
$M_{4} D_{3}$ & $100,540 \mathrm{gh}$ \\
$M_{4} D_{4}$ & $116,267 \mathrm{~h}$ \\
$B N T$ & 14,135
\end{tabular}

Keterangan: Angka-angka yang didampingi huruf yang sama pada kolom yang sama tidak berbeda nyata $\mathrm{p}=0,05$ (Uji Beda Nyata Terkecil)

Tabel 9. Pengaruh dosis pupuk organik MOL dan komposisi media terhadap berat kering sawi (gr)

\begin{tabular}{cc}
\hline Perlakuan & Rata-rata Berat Kering Tanaman (gr) \\
\hline$M_{1} D_{1}$ & $6,375 \mathrm{ab}$ \\
$M_{1} D_{2}$ & $6,067 \mathrm{ab}$ \\
$M_{1} D_{3}$ & $6,326 \mathrm{ab}$ \\
$M_{1} D_{4}$ & $10,210 \mathrm{~d}$ \\
$M_{2} D_{1}$ & $8,988 \mathrm{bcd}$ \\
$M_{2} D_{2}$ & $4,409 \mathrm{a}$ \\
$M_{2} D_{3}$ & $5,320 \mathrm{ab}$ \\
$M_{2} D_{4}$ & $5,555 \mathrm{ab}$ \\
$M_{3} D_{1}$ & $5,343 \mathrm{ab}$ \\
$M_{3} D_{2}$ & $9,426 \mathrm{~cd}$ \\
$M_{3} D_{3}$ & $9,959 \mathrm{~cd}$ \\
$M_{3} D_{4}$ & $11,987 \mathrm{~d}$ \\
$M_{4} D_{1}$ & $5,725 \mathrm{ab}$ \\
$M_{4} D_{2}$ & $8,182 \mathrm{bc}$ \\
$M_{4} D_{3}$ & $7,352 \mathrm{ab}$ \\
$M_{4} D_{4}$ & $12,290 \mathrm{~d}$ \\
\hline$B_{1}{ }_{2} \%$ & 3,722
\end{tabular}

Keterangan: Angka-angka yang didampingi huruf yang sama pada kolom yang sama tidak berbeda nyata $\mathrm{p}=0,05$ (Uji Beda Nyata Terkecil) 


\section{KESIMPULAN}

Dari hasil penelitian pengaruh dosis pupuk organik MOL dan komposisi media tanam terhadap pertumbuhan dan hasil tanaman sawi jabung (Brassica juncea) dapat disiimpulkan sebagai berikut:

1. Terjadi interaksi antara perlakuan dosis pupuk organik MOL dan media tanam pada semua parameter pengamatan, yaitu: tinggi tanaman, jumlah daun, luas daun, jumlah akar, panjang akar, berat basah dan berat kering tanaman per tanaman.

2. Pertumbuhan tanaman terbaik ditunjukkan oleh kombinasi perlakuan $\quad \mathrm{D}_{4} \mathrm{M}_{4}, \quad$ yang menghasilkan: rata-rata tinggi tanaman, jumlah daun, luas daun, jumlah akar dan panjang akar terbesar.

3. Hasil tanaman terbesar ditunjukkan perlakuan $M_{4} D_{4}$, yaitu rata-rata berat basah tanaman per tanaman $(116,267 \mathrm{gr})$ dan rata-rata berat kering tanaman per tanaman $(12,290 \mathrm{gr})$.

\section{UCAPAN TERIMA KASIH}

Kami sebagai penulis ingin memberikan penghargaan secara khusus untuk Universitas Kadiri atas dukungan finansial yang diberikan dalam membantu kelancaran jalannya penelitian ini. Penulis juga ingin mengucapkan terima kasih kepada rekan-rekan kami di Fakultas Pertanian Universitas Kadiri atas bantuannya dalam kepenyusunan artikel dan peminjaman green house sebagai sarana penelitian, badan dan kelembagaan pemerintah terkait dengan data yang diperoleh untuk mendukung penyusunan artikel, serta segenap pihak yang tidak dapat kami sebutkan satupersatu baik yang secara langung maupun tidak langsung tlah membantu kami dalam melaksanakan penelitian dan penulisan artikel ini.

\section{DAFTAR PUSTAKA}

Alavan, A., Hayati, R., \& Hayati, E. (2015). Pengaruh Pemupukan Terhadap Pertumbuhan Beberapa Varietas Padi Gogo (Oryza sativa L.). Jurnal Floratek, 10(1), 61-68. https://doi.org/10.24815/floratek.v1 $0 \mathrm{i} 1.2331$

Cholisoh, K. N., Budiyanto, S., \& Fuskhah, E. (2018). Pertumbuhan dan produksi tanaman sawi (Brassica juncea I.) akibat pemberian pupuk urin kelinci dengan jenis dan dosis pemberian yang berbeda. Agro Complex, 2(October), 275-280. https://doi.org/doi.org/10.14710/joa c. $2.3 .275-280$

Erawan, D., Yani, W. O., \& Bahrun, A. (2013). Growth and Yield of Mustard ( Brassica juncea L .) under Various Dosages of Urea Fertilizer. Jurnal Agroteknos, 3(1), 19-25.

Firdaus, F., Purwanto, B. P., \& Salundik. (2014). Dosis Penggunaan Mikroorganisme Lokal (Mol) Ragi Tempe Dan Isi Rumen Untuk Pengomposan. Jurnal IImu Produksi Dan Teknologi Hasil Peternakan, 2(1), 257-261. https://doi.org/10.29244/jipthp.2.1.2 57-261

Gustia, H. (2013). Pengaruh Penambahan Sekam Bakar Pada Media Tanam Terhadap Pertumbuhan dan Produksi Tanaman Sawi (Brassica juncea L.). E-Journal WIDYA Kesehatan Dan Lingkungan, 1(1), 12-17. https://doi.org/10.1016/j.ocl.2008.0 
5.004

Iradhatullah, R., Yunarti, \& Sunarti. (2016). Pemanfaatan Buah Maja Dan Bonggol Pisang Sebagai Sumber Mikroorganisme Lokal (MOL) Dan Bahan Organik Untuk Pertumbuhan Dan Produksi Cabe. Jurnal Agrotan, 2(2), 85-93.

Jeksen, J., \& Mutiara, C. (2018). Pengaruh Sumber Bahan Organik Yang Berbeda Terhadap Kualitas Pembuatan Mikroorganisme Lokal (Mol). Agrica, 11(1), 60-72. https://doi.org/10.37478/agr.v11i1.2 3

Julita, S., Gultom, H., \& Mardaleni. (2013). Pengaruh Pemberian Mikro Organisme Lokal (MOL) Nasi Dan Hormon Tanaman Unggul Terhadap Pertumbuhan Dan Produksi Tanaman Cabai ( Capsicum Annum L .) Influence of giving Local Microorganism of Rice and Superior Plant Hormone on Growth and Yield of Chilli ((. Jurnal Dinamika Pertanian, XXVIII(3), 167-174.

Junaidi. (2017). Pengaruh Interaksi Macam Pupuk Kandang Dan Dosis Terhadap Parameter Pertumbuhan Dan Hasil TANAMAN PADI. Agrinika, 1(2), 154-167. https://doi.org/10.1017/CBO978110 7415324.004

Kurniawan, A. (2018). MOL Production (Local Microorganisms) With Organic Ingredients Utilization Around Produksi MOL ( Mikroorganisme Lokal ) Dengan Pemanfaatan. Jurnal Hexagro, 2(2), 36-44.

Kustiani, E. (2018). Aplikasi Pupuk Organik Cair (Urin Sapi) Dan Populasi Pada Kangkung Darat (Ipomoea reptans Poir.). Agrinika, 2(2), 103-114.
Manullang, R. R., Rusmini, R., \& Daryono, D. (2018). Kombinasi Mikroorganisme Lokal Sebagai Bioaktivator Kompos Combination of Local Microorganism as Compose Bioactivators. Jurnal Hutan Tropis, 5(3), 259. https://doi.org/10.20527/jht.v5i3.47 93

Nurliana, Noviyanti, A., \& Azwir. (2017). Identifikasi Tanaman Sayuran di Desa Cot Yang Aceh Besar. Serambi Saintia, V(1), 55-63.

Perwtasari, B., Tripatmasari, M., \& Wasonowati, C. (2012). Pengaruh Media Tanam Dan Nutrisi Terhadap Pertumbuhan Dan Hasil Tanaman Pakchoi (Brassica juncea L.) Dengan Sistem Hidroponik. Agrovigor, 5(1), 14-25. https://doi.org/ISSN 19795777

Rinanto, Y., Sajidan, \& Fatmawati, U. (2015). Pemanfaatan Limbah Sisa Hasil Panen Petani Sayuran di Boyolali sebagai Bahan Baku Pembuatan Pupuk Cair Organik menuju Pertanian Ramah Lingkungan. Seminar Nasional Konservasi Dan Pemanfaatan Sumber Daya Alam 2015, 231236.

Sangaji, Z. (2017). Kajian Sistem Budidaya Tanaman Sawi (Brassica juncea L ) Di Petani Kelurahan Malawele Distrik Aimas Kabupaten Sorong. Median, 9(1), 16-24.

Sarif, P., Hadid, A., \& Wahyudi, I. (2015). Akibat Pemberian Berbagai Dosis Pupuk Urea. J. Agrotekbis 3, 3(5), 585-591.

Subandi, M., Salam, N. P., Jurusan, F., Uin, A., Gunung, S., \& Bandung, D. (2015). Pengaruh Berbagai Nilai Ec (Electrical Conductivity) Terhadap Pertumbuhan dan Hasil Bayam (Amaranthus sp.) Pada Hidroponik Sistem Rakit Apung (Floating 
Hydroponics System). Jurnal Istek, 9(2), 136-152.

Sulastri, Sutejo, H., \& Fatah, A. (2018). Respon Pertumbuhan Dan Hasil Tanaman Sawi Hijau (Brassica juncea L.) Pada Pemberian Pupuk Organik Cair Agrobost. Jurnal Agrifor, XVII(2), 375-384.

Wicaksana, P. C., \& Sulistyono, N. B. E. (2017). Aplikasi Pupuk Kandang Ayam dan Mikroorganisme Lokal (MOL) Daun Gamal Terhadap Produksi dan Mutu Benih Mentimun (Cucumis sativus L.). Agriprima, Journal of Applied Agricultural Sciences, 1(1), 72-85. https://doi.org/10.25047/agriprima.v $1 \mathrm{i} 1.8$

Wulandari, D. A. (2015). Penggunaan Em4 Dan Mol Limbah Tomat Sebagai Bioaktivator Pada Pembuatan Kompos. In Universitas Negeri Semarang. Universitas negeri Semarang. 